\title{
Ciência e tecnologia: indispensáveis!
}

A força da ciência não está na revista científica tipo celebridade em que foi publicada, e sim no método utilizado e descrito de forma detalhada para que qualquer um, em qualquer lugar do mundo, sob as mesmas condições, possa repetir o trabalho e chegar ao mesmo resultado ou resposta. Assim preconizou Descartes e que se publique outros trabalhos confirmando seus resultados e interpretações.

A ciência produz o novo conhecimento a partir de uma pergunta bem formulada e sem resposta na literatura científica. Depois da pergunta sem resposta, vem outra pergunta: como é que poderemos responder, qual a metodologia, como iremos organizar os testes para checar as respostas que procuraremos obter?

Uma vez obtida a resposta para a pergunta formulada, se conclui e apresenta a pesquisa completa para ser publicada e que todos tomem acesso ao conhecimento do novo se assim procurar na literatura via banco de dados.

Quantas mais vezes o trabalho for citado, é porque ele foi confrontado, repetido e analisado muitas vezes. Se assim for, quanto mais citado, mais confiável ele será! É interessante perguntar se aquele trabalho está confirmando resultados já obtidos ou se é inédito: ambos têm grandes valores embutidos!

Muitos trabalhos são publicados em revistas sem acesso a grande mídia, mas se o método respondeu a uma pergunta formulada de forma intrigante e inédita, com certeza logo ele será resgatado e alcançará o reconhecimento via citações e republicações, inclusive na mídia eletrônica. Assim aconteceu na USP com Mauricio Rocha e Silva, o descobridor das cininas cuja história pode servir de exemplo para todos nós!

$\mathrm{Na}$ tecnologia não se publica nada do que foi descoberto, apenas se registra e ganha-se o direito de explorar o novo conhecimento comercial e industrialmente via patentes e marcas registradas. Pode se simplificar assim: ciência é pública e aberta para todas, enquanto tecnologia é privada e restrita ao comércio e indústria.

Toda revista publica trabalhos científicos, mas também seria muito interessante que os pesquisadores comunicassem a elas descrevendo as suas patentes e marcas comerciais obtidas para que mais pessoas soubessem que seus trabalhos científicos, às vezes, viram antes tecnologia e traz benefícios econômicos, sociais e geopolíticos para o país!

Sem ciência e sem tecnologia não há desenvolvimento e muito menos inovação. Ciência e tecnologia são as ferramentas mais poderosas para que em poucos anos uma instituição, cidade, estado ou país sejam considerados evoluídos, com poucos problemas a serem resolvidos e ganhem o respeito da humanidade.

Neste número, analise os trabalhos publicados e veremos que estamos no caminho certo. Persistamos, mesmo com as condições adversas, chegaremos lá e sempre conscientes!

Prof. Dr. Alberto Consolaro 